\title{
Evaluation of the Productive Zakat Program of BAZNAS: A Case Study from Western Indonesia
}

\author{
Mohamad Soleh Nurzaman ${ }^{1}$ \\ University of Indonesia \\ Ninik Annisa, Ridho Gusti Hendharto, Khairunnajah, Noviyanti \\ The National Board of Zakat (BAZNAS) The Republic of Indonesia
}

\begin{abstract}
This paper aims to measure the impact of zakat distribution program implemented by Indonesia's National Zakat Board (BAZNAS). The study intended to accurately assess the impact of the program for a potential extension to other zakat institutions. The studyadopted theCIBEST model developed by Beik and Arsyianti (2015), a quadrant model that combines the fulfillment of human needs that are both material and spiritual. The CIBEST consists of well-being index, material poverty index, spiritual poverty index, and absolute poverty index. The study has found that fund distribution by BAZNAS through the productive zakat program is quite effective in improving the welfare index of mustahik households in both material and spiritual aspects.
\end{abstract}

Keywords: CIBEST model, Mustahik, Productive Zakat

${ }^{1}$ Corresponding author : dedenmsn@gmail.com 


\section{INTRODUCTION}

Zakat is one of the social and economic instruments for an optimum development of a nation (Qaradawi, 2011). It is also projected to reduce poverty and empower the poor. In Indonesia, poverty is still a major economic and social problem that needs to be alleviated. The Indonesia State Statistical Office (Badan Pusat Statistik) has reported in September 2015 thatthe number of poor people were about 28.51 million, or $11.13 \%$ of the total population of Indonesia. Therefore, it is interesting to see how charity plays a role in poverty alleviation.

Based on a study by Firdaus et al. (2012), the zakat fundingin Indonesia reached $3.4 \%$ of total GDP in 2011, or Rp 217 trillion. The potential of zakat was estimated to reach Rp 286 trillion by 2015 . However, the realization of zakat colletion was only about $2 \%$ of its potential. The lack of public trust to pay zakat though zakat institutions was believed to be a major reasonfor the wide gap between potential and actual collection of zakat in Indonesia.

The management of zakat in Indonesia has been regulated through the Law No. 23 of 2011, replacing the Law No. 38 of 1999. The law prescribes that there are two kinds of zakat organizations in Indonesia, namely Badan Amil Zakat Nasional (BAZNAS), representing zakat governments throughout Indonesia, and Amil Zakatinstitutions (LAZ) managed privately or publically withapproval and accreditation from the government (the Ministry of Religious Affairs of the Republic of Indonesia). By law, BAZNAS has the authority to manage and coordinate with all zakat institutions, including LAZ, in Indonesia. Currently, BAZNAS has 33 representatives across all provinces ofIndonesia. Hence, BAZNAS is at frontline in national development, especially related to poverty reduction.

To meets their expected goals, BAZNAS andother zakat institutionsshould adopt precise ways to accurately measure the impact of the program onthe welfareof mutashik. The evaluation should especially measurehow effective the zakat program has been in improving the lives of mustahik in economic, social, and spiritual aspects.

Under BAZNAS, the distribution of zakat funds as on 2015 reached $\mathrm{Rp}$ $2,251,634,745,545 \quad(2.2 \quad$ trillion $)$, benefitting $4,515,126$ or 4.5 million people. Based on the types (asnaf) of mustahik who receivedbenefit,about $67.7 \%$ of the population were categorized as poor (BAZNAS, 2015). Based on the distribution of funds by sectors, about $41.3 \%$ were allocated to the social and humanitarian sector, followed by $20.3 \%$ toeducation, $15 \%$ to economic sector, $14.9 \%$ to da'wah, and $8.5 \%$ to health sector. It is clear that zakat funds are aimed to increase the economic productivityof mustahik communities, and hence BAZNAS must ensure that the funds are effectively distributed to improve the welfareof mustahik families.

\section{LITERATURE REVIEW}

To assess whether zakat funding has an impact on reducing the poverty, we require some economic tools to measure the impact. We can use a variety of models. To assesspoverty levels among zakat recipients (mustahik), the World Bank'sHandbook on Poverty and Inequality describes several methods that are of interest (Haughton \& Khandker, 2009).A study by Haughton and Khandker also explains several indices that can be used to measure poverty. The models are summarized in Table 1.

Table 1 Poverty Measurement Indices(World Bank Version)

\begin{tabular}{ll}
\hline $\begin{array}{c}\text { Measurement } \\
\text { Model }\end{array}$ & \multicolumn{1}{c}{ Explanation } \\
\hline $\begin{array}{l}\text { Headcount } \\
\text { Index }\end{array}$ & $\begin{array}{l}\text { The percentage of poor people } \\
\text { under the poverty line }\end{array}$ \\
\end{tabular}




\begin{tabular}{|c|c|}
\hline $\begin{array}{l}\text { Poverty } \\
\text { GapIndex }\end{array}$ & $\begin{array}{l}\text { This index is a continuation of } \\
\text { Headcount Index that measures } \\
\text { the extent to which a person falls } \\
\text { below the poverty line (poverty } \\
\text { gap) }\end{array}$ \\
\hline $\begin{array}{l}\text { Poverty } \\
\text { Severity Index }\end{array}$ & $\begin{array}{l}\text { This index is used to measure the } \\
\text { inequality among the poor, or to } \\
\text { observe the rate of severity of the } \\
\text { poor by measuring the gap } \\
\text { between poverty line and the } \\
\text { average income of poor people }\end{array}$ \\
\hline $\begin{array}{l}\text { Sen-Shorrocks- } \\
\text { Thon (SST) } \\
\text { Index }\end{array}$ & $\begin{array}{l}\text { This index is a combination of } \\
\text { Headcount Index, Poverty Gap } \\
\text { Index (applied to the poor only), } \\
\text { and a term with Gini coefficient } \\
\text { of the poverty gap ratios (for the } \\
\text { whole population). So the } \\
\text { formula is, \%change in SST } \\
\text { index = \%change in Headcount } \\
\text { Index + \%change in Poverty Gap } \\
\text { Index (among poor) + \%change } \\
\text { in (1+Gini coefficient of poverty } \\
\text { gap) }\end{array}$ \\
\hline Watts Index & $\begin{array}{l}\text { The measure } \\
\text { "distributionallysensitive" is } \\
\text { virtue of its use of } \\
\text { logarithms. The Watts index is } \\
\text { more sensitive to changes in the } \\
\text { lowest incomes than it is to } \\
\text { changes for those with higher } \\
\text { incomes. That is, transferring } \$ 5 \\
\text { to a very poor person counts as a } \\
\text { far larger contribution to poverty } \\
\text { reduction than transferring } \$ 5 \text { to } \\
\text { a richer (but still poor) neighbor }\end{array}$ \\
\hline
\end{tabular}

Source: World Bank (2009).

In Indonesia, there are two approaches tomeasuring the poverty standard, introduced by BPS-Statistics Indonesia and National Board of Family Planning Coordination (BKKBN). BPS has proposedan approach based on spending for basic needs, which consists of food consumption and non-food consumption. For food consumption, BPS determinedaminimum supply of 2,100 calories per day per capita. It means that if a person consumesless than 2,100 calories per day, then he/she is classified as poor based on the food poverty line. For nonfood consumption, BPS determined the commodity needs per person depending on the geographical conditions. For the rural area, there are at least 47 commodities, while for the urban area there are 51 commodities. If a person cannot fulfill this commodity standard, he/she is categorized as poor people based on the non-food poverty line. For further computation, both indices are technically converted into monetary terms.

While BPS calculates the basic needs per capita, BKKBN qualitatively measures poverty based onbasic needs of afamily. In this regard, BKKBN classifies families into five groups, namely preprosperous family, prosperous families I, prosperious family II, prosperious family III, and prosperous family III plus. BKKBN also incorporates spiritual needs as one of the indicators of a prosperous family II (non-poor family). Spiritual need is determined based on the ability to perform rituals; if a family cannot fulfill its spiritual needs, it will be classified as prosperous family I (poorfamily) (Alimoeso, 2014). Nevertheless, the BKKBN model seems less comprehensivein elaborating spiritual needs.

Based on a review of literature, most of the existing models cannot adequately measure the expectations of zakat in terms of not only material needs but also spiritual needs. However, the CIBEST model, developed by Beik and Arsyianti (2015),attempts to address this challenge by measuring both the material and spiritual needs. Both aspects are important benchmarksfor a person's balancedway of life, as revealed the Qur'an and Sunnah. Within this model, households are divided into four types based on the conditions and their capacity to meet the material and spiritual needs. The four types are:

1. Prosperous family (quadrantI): In this highest category, a household can meet both material and spiritual needs completely.

2. Material poverty (quadrant II): In this, a family is only able to meet spiritual needs but not material needs. 
3. Spiritual poverty (quadrant III): In this, a family is only able to meet material needs but not spiritual needs.

4. Absolut poverty (quadrant IV): In this lowest level, a family canmeet neither the material needs nor the spiritual needs.

Based on this classification, Beik and Arsyianti formulated an index called CIBEST, with quadrants as shown in Figure 1.

Figure 1 CIBEST Quadrants

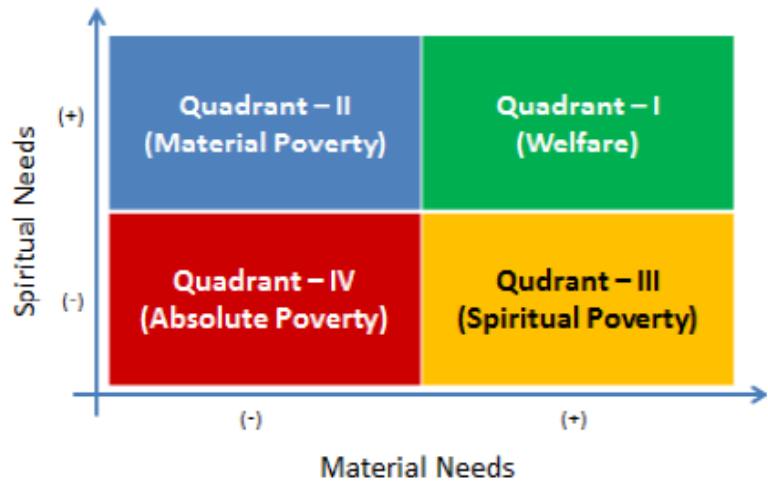

Source: Beik and Arsyianti (2015).
There are two benefits in using theCIBEST model. First, the number of families in each quadrant can be easily identified. Second, the quadrantscanassist government agencies in formulating appropriate policies. According to Beik and Arsyianti, material poverty line can be determined using three approaches: periodical surveys of basic material needs, determining a standard poverty line according to BPS, and zakat standard nishab (the minimum amount that a muslim must have before being obliged to zakat). Nishab is a standard between muzaki (zakat payers) and mustahik (zakat recipients).In the CIBEST model,the spiritual aspects are based on three variables, consisting of worship, family environment, and government policies. The measurement of these three variables is outlined in Table 2. 
Table 2Assessment of Spiritual Needs

\begin{tabular}{|c|c|c|c|c|c|c|}
\hline \multirow[t]{2}{*}{ Variables } & \multicolumn{5}{|c|}{ Likert Scale } & \multirow{2}{*}{$\begin{array}{l}\text { Poverty } \\
\text { Standard }\end{array}$} \\
\hline & 1 & 2 & 3 & 4 & 5 & \\
\hline Prayer & $\begin{array}{l}\text { Blocking } \\
\text { others to pray }\end{array}$ & $\begin{array}{l}\text { Against the } \\
\text { concept of } \\
\text { prayer }\end{array}$ & $\begin{array}{l}\text { Performing } \\
\text { obligatory } \\
\text { prayer but } \\
\text { not on regular } \\
\text { basis }\end{array}$ & $\begin{array}{l}\text { Always } \\
\text { performing } \\
\text { obligatory } \\
\text { prayer but not } \\
\text { in } \\
\text { congregational } \\
\text { prayer }\end{array}$ & $\begin{array}{l}\text { Performing } \\
\text { congregational } \\
\text { prayer for } \\
\text { obligatory one } \\
\text { and perform } \\
\text { recomendedpra } \\
\text { yer }\end{array}$ & \multirow{5}{*}{$\begin{array}{c}\text { Average } \\
\text { score for } \\
\text { spiritually } \\
\text { poor } \\
\text { household is } \\
\text { equal to } 3 \\
(S V=3)\end{array}$} \\
\hline Fasting & $\begin{array}{l}\text { Blocking } \\
\text { others to } \\
\text { undertaking } \\
\text { fasting }\end{array}$ & $\begin{array}{l}\text { Against the } \\
\text { concept of } \\
\text { fasting }\end{array}$ & $\begin{array}{l}\text { Not fully } \\
\text { performing } \\
\text { obligatory } \\
\text { fasting }\end{array}$ & $\begin{array}{l}\text { Performing only } \\
\text { obligatory } \\
\text { fasting }\end{array}$ & $\begin{array}{l}\text { Performing } \\
\text { obligatory } \\
\text { fasting and } \\
\text { recomendable } \\
\text { fasting }\end{array}$ & \\
\hline Zakat and Infak & $\begin{array}{l}\text { Blocking } \\
\text { others to pay } \\
\text { zakat and } \\
\text { infak }\end{array}$ & $\begin{array}{l}\text { Against the } \\
\text { concept of } \\
\text { zakat and } \\
\text { infak }\end{array}$ & $\begin{array}{l}\text { Not paying } \\
\text { infak at least } \\
\text { once in a year }\end{array}$ & $\begin{array}{l}\text { Paying zakat al- } \\
\text { fitr and zakat al- } \\
\text { maal }\end{array}$ & $\begin{array}{l}\text { Paying zakat al- } \\
\text { fitr, zakat al- } \\
\text { maal, and infak }\end{array}$ & \\
\hline $\begin{array}{l}\text { Household } \\
\text { Environment }\end{array}$ & $\begin{array}{l}\text { Forbid } \\
\text { ibaadah }\end{array}$ & $\begin{array}{l}\text { Against } \\
\text { implementati } \\
\text { on of ibaadah }\end{array}$ & $\begin{array}{l}\text { Consider } \\
\text { ibadaah as } \\
\text { private } \\
\text { matter for } \\
\text { household } \\
\text { member }\end{array}$ & $\begin{array}{l}\text { Support } \\
\text { execution of } \\
\text { ibaadah }\end{array}$ & $\begin{array}{l}\text { Creating } \\
\text { environment } \\
\text { which obligates } \\
\text { execution of } \\
\text { ibaadah }\end{array}$ & \\
\hline $\begin{array}{l}\text { Government } \\
\text { Policy } \\
\text { Environment }\end{array}$ & $\begin{array}{l}\text { Forbid } \\
\text { ibaadah }\end{array}$ & $\begin{array}{l}\text { Against } \\
\text { implementati } \\
\text { on of ibaadah }\end{array}$ & $\begin{array}{l}\text { Consider } \\
\text { ibaadah as } \\
\text { private } \\
\text { matter }\end{array}$ & $\begin{array}{l}\text { Support } \\
\text { execution of } \\
\text { ibaadah }\end{array}$ & $\begin{array}{l}\text { Creating } \\
\text { environment } \\
\text { which obligates } \\
\text { execution of } \\
\text { ibaadah }\end{array}$ & \\
\hline
\end{tabular}

Source: Beik andArsyianti (2015)

The CIBESTmodeluses a Likert-typescale to measure spiritual needs, where 1 is the lowest value and 5 is the highest value. Although a value of 3 is a minimum standard to distinguish the poor and the rich based on spiritual needs,afamily receiving this score is considered to lack faith in performing regular worship. Afamily scoring a value of 1 and 2 can be assumed to be not adheringto Islamic teachings, suggesting that the household environment and the government are against religious teachings.

\section{METHODOLOGY}

\section{Data}

The present study is a quantitative analysis of data obtained through a survey of mustahik who were recipients of the productive zakat program. The CIBEST model developed by Beik and Arsyianti (2015) was used to measure the impact of zakat. The CIBEST model consists of Well-being Index, Material Poverty Index, 
Spiritual Poverty Index, and Absolute Poverty Index.

This study considered both primary and secondary data. While the primary data were obtained through interviewsof mustahik, the secondary data were derived from the documents and financial reports of BAZNAS. The methods of data collection used in this study are detailed in
Table 3.Interview data were collected between October and November 2016 from six districts, which included West Sumatra (Sijunjung), Riau (Siak), West Java (Bandung and Sumedang), Yogyakarta (Bantul), and East Java (Gresik) (Table 4).

Table 3Methods of data collection

$\begin{array}{lll}\text { I Secondary data } & \text { BAZNAS documentation and } \\ \text { literature review } & \text { Direct survey of mustahik } & \begin{array}{l}\text { Findings related to the research on } \\ \text { the impact of zakat program }\end{array} \\ \text { II Primary data } & \begin{array}{l}\text { Profiles, trends, and life patterns } \\ \text { of mustahik receiving zakat }\end{array}\end{array}$

Tabel 4 Province, areas, and number of respondents

\begin{tabular}{clcr}
\hline No & \multicolumn{1}{c}{ Province } & Areas Surveyed & Number of Respondents \\
\hline 1 & West Sumatra & Sijunjung & 150 \\
2 & Riau & Siak & 400 \\
3 & West Java & Sumedang & 85 \\
& & Bandung Barat & 63 \\
4 & Yogyakarta & Bantul & 104 \\
5 & East Java & Gresik & 200 \\
& \multicolumn{1}{c}{ Total } & & $\mathbf{1 , 0 0 2}$ \\
\hline
\end{tabular}

Sumber: Primary data 2016 (processed).

The survey data obtained from 1,002 respondents wereverified and validated before analysis.

\section{Methods of Data Analysis}

\section{a. Material Poverty Line}

The BPS-Statistics Indonesia standard of poverty line was modified considering the data of year before zakat program was started and theyear after the program started. Furthermore, the unit analysis wasbased on household instead of individual. Based on this, the households were categorized into either below poverty line or above poverty line. The formulasused were as follows:

- Material poverty line before start of the program: Poverty line of BPS yearbefore $\mathrm{x}$ average number of family members per household yearbefore
- Material poverty line after start of the program: Poverty line of BPS yearafter $\mathrm{x}$ average number of family members per household yearafter

b. Average Score of Spiritual Conditions of All Households

CIBEST requires the score of actual spiritual conditions of households. The spiritual score of each individual household was obtained using the following formula:

$$
H i=\frac{V p i+V f i+V z i+V h i+V g i}{5}
$$

where

$H i$ : spiritual score of household member i Vpi : prayer score of household member i $V f i$ : fasting score of household member i 
$V z i$ : score of zakat and infak of household member i

Vhi : score of household environment based on perception of household member i

$V g i$ : score of government policy environment based on the perception of household member i

Then, anaverage score of spiritual conditions of one household was obtained:

$$
S H=\sum_{h=1}^{n} \frac{H 1+H 2+\cdots+H n}{M H}
$$

where

SH : average score of spiritual condition of one household

$H h$ : spiritual score of household member i

$M H$ : total number of household members
From the average score of spiritual condition of one household, the average score of spiritual condition of all households was estimated using the following formula:

$$
S S=\sum_{k=1}^{n} \frac{S H k}{N}
$$

where

SS : average score of spiritual condition of all observed households

$S H k$ : spiritual score of household $k$

$N$ : total number of observed households

After obtaining the material poverty line and average score of spiritual condition, each household is then categorized according to the CIBEST quadrant as shown in Table 5.

Table 5Classification of Households Based on Material Poverty Index (MV) and Spiritual Poverty Index (SV)

\begin{tabular}{lll}
\hline & \multicolumn{1}{c}{$\leq$ MV Score } & \multicolumn{1}{c}{$>$ MV Score } \\
\hline$>$ SV Score & $\begin{array}{l}\text { Spiritually rich but materially poor } \\
\text { household (quadrant II) } \\
\text { Materially and spiritually poor household } \\
\text { (quadrant IV) }\end{array}$ & $\begin{array}{l}\text { Materially and spiritually rich household } \\
\text { (quadrant I) } \\
\text { Materially rich and spiritually poor } \\
\text { household (quadrant III) }\end{array}$ \\
\hline
\end{tabular}

Source: Beik and Arsyianti (2015)

Table 6Formulas of CIBEST Indices

\begin{tabular}{cll}
\hline CIBEST Indices & Formula & \multicolumn{1}{c}{ Narration } \\
\hline Material Poverty & $P m=\frac{M p}{N}$ & $\begin{array}{l}P m: \text { Material Poverty Index; } 0 \leq P m \leq 1 \\
M p: \text { number of materially poor and spiritually rich households } \\
N: \text { total number of observed households }\end{array}$ \\
& $P s=\frac{S p}{N} \quad \begin{array}{l}P s: \text { Spiritual Poverty Index; } 0 \leq P s \leq 1 \\
S p: \text { number of spiritually poor and materially rich households } \\
N: \text { total number of observed households }\end{array}$ \\
\hline Spiritual Poverty & $P a=\frac{A p}{N}$ & $\begin{array}{l}P a: \text { Absolute Poverty Index; } 0 \leq P a \leq 1 \\
A p: \text { number of spiritually and materially poor households } \\
N: \text { total number of observed households }\end{array}$ \\
& \multirow{2}{*}{$W=\frac{W}{N}$} & $\begin{array}{l}W: \text { Welfare Index; } 0 \leq W \leq 1 \\
w: \text { number of spiritually and materially rich households } \\
N: \text { total number of observed households }\end{array}$ \\
\hline Welfare &
\end{tabular}

\section{RESULTS AND ANALYSES}

\section{Measurement of CIBEST}

Using a modified BPS approach, the value of MV (material poverty line) forthe year before and after the zakat program was introduced was determined. The results of the calculations based on the data fromthe surveys conducted in sixdistricts are presented in stages. 


\section{Stage I: MV before and after zakat program}

In our study areas, zakat program was either started in the end of 2014 or the beginning of 2015.

Material poverty line before zakat program (MV1): Poverty line of BPS yearbefore (2014) $\mathrm{x}$ average number of family members per household yearbefore MV1 = Rp 311,767 x $4=\operatorname{Rp} \mathbf{1 , 2 4 7 , 0 6 8}$

Material poverty line after zakat program (MV2): Poverty line of BPS yearafter (2016)x average number of family members per household year-after MV2 = Rp 354,087 x $4=\operatorname{Rp~1,416,346~}$

\section{Stage II:Spiritual value and monthly income}

For the calculation of spiritual value by CIBEST mode, five indicators were considered, including prayer, fasting, zakat and donation, households' environment, and government policies. Based on oursurvey in sixareas, the results of spiritual value is presented in Table 7.

Table 7Average spiritual score of mustahik households

\begin{tabular}{cc}
\hline $\begin{array}{c}\text { Pre zakat } \\
3.82\end{array}$ & $\begin{array}{c}\text { Post zakat } \\
4.13\end{array}$ \\
\hline Source: & Primary data 2016 (processed). \\
The & spiritualityofmustahik
\end{tabular}
households has relatively increased after the implementation of zakat program, which included da'wa program in the form of public lectures at mosques. With regard to the changes in the income of mustahik households, the average monthly income significant increased from $\mathrm{Rp} 1,490,937$ to

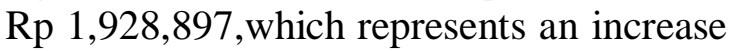
of $41 \%$. The average incomes in the six regions surveyed are presented in Table 8 .

Table 8Average monthly incomes of mustahik households

\begin{tabular}{ccrrr}
\hline No & Region & Prezakat(Rp) & Postzakat(Rp) & Percentage Increase \\
\hline 1 & Bandung Barat & $1,678,791$ & $2,059,585$ & 22.68 \\
2 & Bantul & $1,998,558$ & $2,550,077$ & 27.60 \\
3 & Sumedang & 371,605 & 814,553 & 119.20 \\
4 & Gresik & $1,754,850$ & $2,103,600$ & 19.87 \\
5 & Sijunjung & $1,590,333$ & $2,014,917$ & 27 \\
6 & Siak & $1,551,482$ & $2,030,648$ & 31 \\
& Average & $\mathbf{1 , 4 9 0 , 9 3 7}$ & $\mathbf{1 , 9 2 8 , 8 9 7}$ & $\mathbf{4 1}$
\end{tabular}

Source: Primary data 2016 (processed).

Based on the average monthly income per mustahik household, fiveareas were slightly above poverty line before the program, and after the program,those areas rose much higher than the poverty line. However, Sumedang is the only region in which the average monthly income before and after the program was still below the poverty line. Nevertheless, there was a significant increase of average monthly income from $\mathrm{Rp} 371,605$ to $\mathrm{Rp} 814,553$, which is $119 \%$. It represents the largest increase among all other regions.

\section{Stage III:Categorizing Mustahik Households into QuadrantsBased on CIBEST Indices}

After determining the poverty line, average monthly income, and spiritual scoreof mustahik households, the next step was to categorize mustahik households into CIBEST quadrants. Based on the data, the prosperity index (W) across the six regions increased by $20 \%$, from 0.54 to 0.64 . Then the Material Poverty Index $(\mathrm{Pm})$ decreased by $17 \%$, Spiritual Poverty Index (Ps) decreased by $67 \%$, and Absolute Poverty $(P a)$ decreased by $100 \%$. The classification of mustahik households 
based on CIBEST indices is shown in Figure 2.

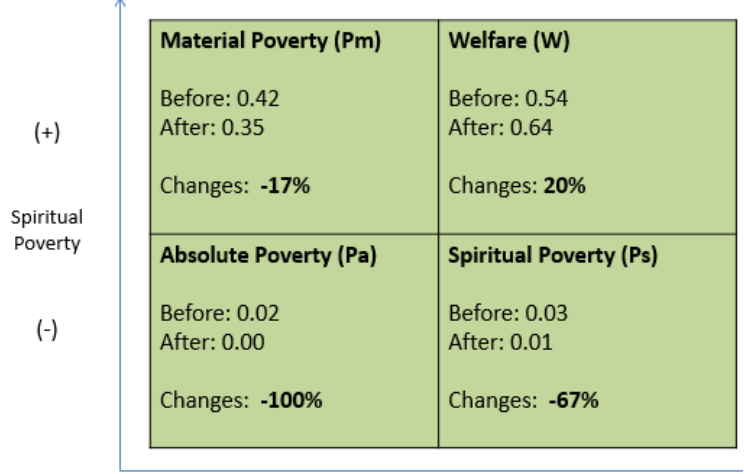

$$
\text { (-) Material Poverty (+) }
$$

Source: Primary data 2016 (processed).

Figure 2 CIBEST quadrants of mustahik households

Based on the data, the increasein welfare index $(W)$ was as a result of increase in both average monthly income and spiritual score. However, it was relatively less significant, with only $20 \%$. It terms of $P m$,it fell by $17 \%$. Although the number of mustahik households in terms of Pswas relatively small, it decreased quite significantly by $67 \%$. It is expected to decrease in the future by $100 \%$. Similarly, absolute poverty decreased significantly, with no mustahik households falling into this category.

Furthermore, the evaluation of zakat impact based on the CIBEST model shows that solutions to obstacles and challenges must be identified in order for the program to achieve maximum outcomes. More optimized action plans should be designed to assist mustahik in improving their welfare in terms of both material and spiritual aspects. Although the number of mustahik families in the spiritual poverty group were small, there is a concern that it may affect their belief inAllah and the teachings of Islam.

Therefore, tofurther improve both material and spiritual aspects of mustahik, more planning, monitoring, and evaluation of zatak distribution is necessary.

The changes in welfare and absolute poverty indicesacross the six areas surveyed are presented in Table 9.

Table 9Changes in indices of welfare and absolute poverty

\begin{tabular}{|l|l|l|c|c|}
\hline No & \multicolumn{1}{|c|}{ Province } & \multicolumn{1}{|c|}{ District } & Changes in $\boldsymbol{W}$ & Changes in $\boldsymbol{P a}$ \\
\hline $\mathbf{1}$ & \multirow{2}{*}{ West Java } & Sumedang & $7.14 \%$ & $0 \%$ \\
\cline { 3 - 5 } & & Bandung Barat & $24.49 \%$ & $0 \%$ \\
\hline $\mathbf{3}$ & Yogyakarta & Bantul & $22.22 \%$ & $-100 \%$ \\
\hline $\mathbf{4}$ & East Java & Gresik & $0 \%$ & $-100 \%$ \\
\hline $\mathbf{5}$ & West Sumatera & Sijunjung & $47.27 \%$ & $-100 \%$ \\
\hline $\mathbf{6}$ & Riau & Siak & $16.95 \%$ & $0 \%$ \\
\hline
\end{tabular}

Source: Primary data 2016 (processed).

According to the table,three districts, Bantul, Sijunjung, and Gresik, have liberated from the absolute poverty group by $100 \%$. Other threedistrictsshowed no change because previously there were no mustahik households in the absolute poverty group. Therefore, based on the increasing welfare index percentage, Sijunjung recorded the highest increasein itswelfare index, by $47.27 \%$, followed by Bandung Barat, by $24.49 \%$, and then Bantul, by $22.22 \%$.
The reason why these threedistricts improved their welfare index was because they have an intensive coaching program and a facilitator. Furthermore, BAZNAS is supervising the mustahik's business in these three districts to ensure their products are well managed, including the cashflow, distribution channel, packaging, etc. Moreover, the mustahik in these areas participate in da'wah activities, including gathering at the mosque or some public space to attend the Islamic public lecture. 
Hence, this study makes it clear that an appropriatecoaching program and a qualified facilitator can influence mustahik's welfare materially and spiritually.

\section{Portrait of the SurveyedAreas}

\section{Siak (Riau)}

The Siak district currently has 14 subdistricts with the total area of $8592.09 \mathrm{~km}^{2}$. The total population in Siak was recordedat 424,884 (Mei 2011). The local government of Siak concerns about zakat and issued Instruction No.14 of 2012, which statesthat all public servants, employees of state-owned enterprises, and other private employees are instructed to pay the zakat to BAZNAS. Zakat socialization in Siak is intensive. Therefore, the zakat collection has been increasing up to this year.

According to Table 10, the value of welfare index pre zakat was 0.59 , but after a productive zakat program, it rose to 0.69 , an increase by $16.95 \%$. Although the material poverty index decreased by $25 \%$, the spiritual poverty index had no change.Moreover, with regard to the absolute poverty index, no single mustahik household fallsin this category both pre and post zakat.

Table 10 CIBEST Indices in Siak

\begin{tabular}{cccc}
\hline & Pre Zakat & Post Zakat & Percentage Change \\
\hline Welfare Index (quadrant 1) & 0.59 & 0.69 & $16.95 \%$ \\
\hline $\begin{array}{c}\text { Material Poverty Index } \\
\text { (quadrant 2) }\end{array}$ & Pre Zakat & Post Zakat & Percentage Change \\
$\begin{array}{c}\text { Spiritual Poverty Index } \\
\quad \text { (quadrant 3) }\end{array}$ & 0.40 & 0.30 & $-25.00 \%$ \\
$\begin{array}{c}\text { Absolute Poverty Index } \\
\text { (quadrant 4) }\end{array}$ & 0.00 & 0.01 & $0.00 \%$ \\
Source: Primary data 2016 (processed). & 0.00 & $0 \%$
\end{tabular}

Generally, BAZNAS has been quite successful in Siak in increasing the welfare index (quadrant 1) and decreasingthematerial poverty index (quadrant 2). However, there is still mustahik households in quadrant 3 (spiritual poverty index).This should not be underestimated. The da'wah program is very important to reduce the spiritual poverty of mustahik households.
'Sijunjung Cerdas',targeting 2,049 poor students, in the first half of 2016. The fund is about $\mathrm{Rp} 609.8$ million. In 2014, BAZNAS in Sijunjung together with BAZNAS National and BAZNAS in West Sumatra had given zakat funds for Zakat Community Development (ZCD) program, amounting to $\mathrm{Rp} 210$ million. Table 11 shows the impact of the distribution of the program in Sijunjung.

\section{Sijunjung(West Sumatra)}

BAZNAS in Sijunjunghas distributed zakat funds for education, called

Table 11 CIBEST Indices in Sijunjung

\begin{tabular}{cccc}
\hline & Pre Zakat & Post Zakat & Percentage Change \\
\hline $\begin{array}{c}\text { Welfare Index } \\
\text { (quadrant 1) }\end{array}$ & 0.55 & 0.81 & $47.27 \%$ \\
$\begin{array}{c}\text { Material Poverty Index } \\
\text { (quadrant 2) }\end{array}$ & 0.34 & 0.18 & $-47.06 \%$ \\
$\begin{array}{c}\text { Spiritual Poverty Index } \\
\text { (quadrant 3) }\end{array}$ & 0.06 & 0.01 & $-83.33 \%$
\end{tabular}


$\begin{array}{llll}\text { Absolute Poverty Index } & 0.05 & 0.00 & -100.00 \%\end{array}$ (quadrant 4)

Source: Primary data 2016 (processed).

Although the welfare index (quadrant 1) significantly increased from 0.55 to 0.81 , an increase by $47.27 \%$, the material poverty index and spiritual poverty index drastically decreased by $47.06 \%$ and $83.33 \%$, respectively. The absolute poverty index also decreased by $100 \%$ post zakat program. Based on these data, we can conclude that zakat in Sijunjung has done very well.

\section{Bandung Barat(West Java)}

BAZNAS distributed zakat to mustahik households in several areas of West Java. In one area located in Bandung Barat, 63 mustahik were surveyed. As shown in Table 12, welfare index increased by $24.49 \%$ after the zakat program. Material poverty index decreased by $23.53 \%$, from 0.51 to 0.39 . Then, spiritual poverty index and absolute poverty index did not change either pre or post zakat program, since there were no mustahik households identified in this group.

Table 12 CIBEST Indices in Bandung Barat

\begin{tabular}{cccc}
\hline & Pre-Zakat & Post-Zakat & Percentage Change \\
\hline $\begin{array}{c}\text { Welfare Index } \\
\text { (quadrant 1) }\end{array}$ & 0.49 & 0.61 & $24.49 \%$ \\
$\begin{array}{c}\text { Material Poverty Index } \\
\text { (quadrant 2) }\end{array}$ & 0.51 & 0.39 & $-23.53 \%$ \\
$\begin{array}{c}\text { Spiritual Poverty Index } \\
\quad \text { (quadrant 3) }\end{array}$ & 0 & 0 & $0 \%$ \\
$\begin{array}{c}\text { Absolute Poverty Index } \\
\text { (quadrant 4) }\end{array}$ & 0 & 0 & $0 \%$ \\
\hline
\end{tabular}

Source: Primary data, 2016 (processed).

It was observed that most of the respondents were factory workers $(15 \%)$, traders $(8.72 \%)$, and some were farmers $(5.96 \%)$. The zakat program in West Bandung focuses on the development of micro entrepreneurs. Many homemakers now do their own businesses, such as bakery, snacks, etc. As a result, the average monthly income of mustahik households increased by $22.68 \%$. Furthermore, the program of 'tabung desa' (village's saving) helpssomeone who needs interest-free loans.

\section{Sumedang (West Java)}

Our survey took place in one of the villages in Sumedang district, called Dayeuh Luhur. Most of the livelihoods of these village communities are based on farming. The number of farmers in this village is $82.05 \%$ of the total population. The rest of them are labors (11.54\%). The survey results are presented in Table 13.

Table 13 CIBEST Indices in Sumedang

\begin{tabular}{|c|c|c|c|}
\hline & Pre Zakat & Post Zakat & Percentage Change \\
\hline $\begin{array}{l}\text { Welfare Index } \\
\text { (quadrant 1) }\end{array}$ & 0.14 & 0.15 & $7.14 \%$ \\
\hline $\begin{array}{l}\text { Material Poverty Index } \\
\quad \text { (quadrant 2) }\end{array}$ & 0.86 & 0.85 & $-1.16 \%$ \\
\hline $\begin{array}{l}\text { Spiritual Poverty Index } \\
\text { (quadrant 3) }\end{array}$ & 0.00 & 0.00 & $0 \%$ \\
\hline
\end{tabular}


Absolute Poverty Index

0.00

0.00

$0 \%$ (quadrant 4)

Source: Primary data 2016 (processed).

Although the majority of mustahiks in this area are still at the level of material poverty, their income increased by $119.20 \%$, which is the highest among the districts surveyed. Their average monthly income per family beforethe program was $\mathrm{Rp}$ 300,000, which increased to $\mathrm{Rp}$ 800,000 after the program. The coaching program by BAZNAS trained mustahik in making local productssuch as banana chips. However, the production of banana chips is constrained by limited land availability and lack of proper distribution and hence the welfare index remains low.

\section{Bantul (Special Region of Yogyakarta)}

In Bantul, there are about 100 mustahik households. Here, people worked in agriculture, farms, and food processing. BAZNAS in Yogyakarta distributed aid in a different form,such as livestock breeding for breeders and money to those who do not have skills in farming, or acombination of both. The results of the survey are presented in Table 14.

Table 14 CIBEST Indices in Bantul

\begin{tabular}{|c|c|c|c|}
\hline & Pre Zakat & Post Zakat & Percentage Change \\
\hline $\begin{array}{l}\text { Welfare Index } \\
\text { (quadrant 1) }\end{array}$ & 0.63 & 0.77 & $22.22 \%$ \\
\hline $\begin{array}{l}\text { Material Poverty Index } \\
\quad \text { (quadrant 2) }\end{array}$ & 0.24 & 0.20 & $-16.67 \%$ \\
\hline $\begin{array}{l}\text { Spiritual Poverty Index } \\
\text { (quadrant 3) }\end{array}$ & 0.09 & 0.03 & $-66.67 \%$ \\
\hline $\begin{array}{l}\text { Absolute Poverty Index } \\
\text { (quadrant 4) }\end{array}$ & 0.05 & 0 & $-100.00 \%$ \\
\hline
\end{tabular}

Source: Primary data 2016 (processed).

The survey shows a low spiritual index in Yogyakarta, 0.03,suggesting that most mustahik households are trapped in spiritual poverty, which may be due to the lack of spiritual coaching. However, the increase in mustahik welfare should be appreciated because of the capital aid that fits their needs.

\section{Gresik (East Java)}

Gresik, located in the northwest of East Java, has a zakat institution that is directly working under the local government. BAZNAS in Gresik has a very broad authority, including zakat collection from all companies or government agencies(SKPD). BAZNAS in Gresik has five main programs: Gresik Cerdas (education), Gresik Sehat (health), Gresik Peduli (social), Gresik Berdaya (economic), and Gresik Taqwa (da'wah).

Gresik Berdaya (economic)has distributed zakat funds in 2015 in the form of interest-free loans to 28 mustahik, working equipments to 3 mustahik, and cattle to126 mustahik. The results of the survey are presented in Table 15.

Table 15 CIBEST Indices in Gresik

\begin{tabular}{cccc}
\hline & Pre Zakat & Post Zakat & Percentage Change \\
\hline $\begin{array}{c}\text { Welfare Index } \\
\text { (quadrant 1) } \\
\begin{array}{c}\text { Material Poverty Index } \\
\text { (quadrant 2) }\end{array}\end{array}$ & 0.84 & 0.84 & $0.00 \%$ \\
& 0.15 & 0.16 & $6.67 \%$
\end{tabular}




$\begin{array}{cccc}\begin{array}{c}\text { Material Poverty Index } \\ \text { (quadrant 2) }\end{array} & 0.01 & 0.00 & -100.00 \% \\ \begin{array}{c}\text { Absolute Poverty Index } \\ \text { (quadrant 4) }\end{array} & 0.01 & 0.00 & -100.00 \%\end{array}$

Source: Primary data 2016 (processed).

Although we can assume that the program successfully improved the spiritual and absolute poverty, the index of mustahik welfare did not increase. This case needs to be evaluated by BAZNAS in Gresik, because although 128 mustahik had directly received benefit, the lack of economic gain could be due to lack of supervision or that farming is unsuitable for mustahik in the particular area.

\section{CONCLUSION AND RECOMMENDATIONS}

The results of our survey point out that the zakat program has beenquite effective in improving the welfare index of mustahik households in both material and spiritual aspects. Our evidence shows that the welfareindex has improved from as low as $7 \%$ to the highest of $47 \%$, except for Gresik which remains unchanged. Moreover, the average monthly income of mustahik households in all areas surveyed has increased from the lowest of $19 \%$ to the highest of $119 \%$. Furthermore, the levels of material poverty, spiritual poverty, and absolute poverty have also decreased.

The findings derived from each region are relatively diverse, due to differences in the social, economic, and culture aspects of mustahik households in a particular area. Furthermore, several factors can be determinant of the outcomes such as the intensity of coaching and monitoring of the program, etc. The distribution of zakat funds in the form of either cash or commodity like cattle, fertilizer, seeds, ora combination of cash and commodity is done to match the needs of mustahik households to establish or expand their businesses.

\begin{abstract}
Coaching and supervision are important to guide the mustahik households in utilizing the distributed zakat fund.Based on the results of our survey, some recommendations can be offered:
\end{abstract}

1. For BAZNAS andother zakat institutions, the strategy of distributing zakat fund and developing the program is very important to ensure that the zakat program meets its intended objectives.

2. BAZNAS and other zakat institutions should adopt material and spiritual aspects of mustahik householdsasperformance indicators.

3. Coaching is very important to ensure sustainability of the zakat program in order that mustahik's business grows and develops independently. Therefore, BAZNAS should act in the capacity of a program manager.

\section{REFERENCES}

Alimoeso, S. 2014, Pemanfaatan data keluarga dalam pembangunan keluarga. Paper presented at National Seminar of BAZNAS, Balikpapan.

Badan Amil Zakat Nasional. (2016). Dokumen Sistem Informasi Manajemen BAZNAS (SIMBA). Jakarta: BAZNAS.

Badan Amil Zakat Nasional. (2016). $\begin{array}{lcr}\text { Dokumen } & \text { Rencana } & \text { Strategis } \\ \text { BAZNAS } & 2016-2020 . & \text { Jakarta: } \\ \text { BAZNAS. } & & \end{array}$ 
Badan Amil Zakat Nasional. (2016). Dokumen Statistik BAZNAS 2016. Jakarta: BAZNAS.

Beik, I. S., \& Arsyianti, L. D. (2016). Ekonomi Pembangunan Syariah (Edisi Revisi). Jakarta: Rajawali Pers. Cetakan ke-1. April 2016

Beik, I. S., \& Arsyianti, L. D. (2016). Measuring Zakat Impact On Poverty And Welfare Using Cibest Model. Journal of Islamic Monetary Economics and Finance, 1(2), 2016th

BKKBN. 2004. Studi Pelaksanaan Program Keluarga Berencana Dalam Era Desentralisasi

BKKBN. 2011. Batasan dan Pengertian MDK, diunduh melalui

http://aplikasi.bkkbn.go.id/mdk/BatasanM DK.aspx

Buku Statistik Zakat Nasional 2015, Divisi IT \& Pelaporan Badan Amal Zakat Nasional/BAZNAS, Agustus 2016

Firdaus, M., Beik, I. S., Irawan, T., Juanda, B. (2012). Economic Estimation and Determinations of Zakat Potential in Indonesia (Working Paper Series WP\#143307). Jeddah: Islamic Research and Training Institute.

http://www.bakti.or.id/berita/zakat-untukpengentasan-kemiskinan-di-kotagorontalo

https://id.wikipedia.org/wiki/Gorontalo

http://www.baznassiak.com/?page_id=1091\#

http://kabsijunjung.baznas.go.id/

Indonesia. Badan Pusat Statistik. Garis Kemiskinan Menurut Provinsi, 20132016. N.p., Oct. 2016. Web. Nov. 2016.

Jonathan Haughton, Shahidur R. Khandker. (2009).Handbook on Poverty and Inequality. The

International Bank for

Reconstruction and

Development/The World

Bank, Washington DC.

Qardawi, Y. (2011). Hukum Zakat. Jakarta: Litera Antarnusa.
Mohamad Soleh Nurzaman

Center of Strategic Studies

The National Board of Zakat (BAZNAS)

Indonesia

mohamad.nurzaman@puskasbaznas.com

Ninik Annisa

Center of Strategic Studies

The National Board of Zakat (BAZNAS)

Indonesia

ninik.annisa@puskasbaznas.com

Ridho Gusti Hendharto

Center of Strategic Studies

The National Board of Zakat (BAZNAS)

Indonesia

ridho.hendharto@puskasbaznas.com

Khairunnajah

Center of Strategic Studies

The National Board of Zakat (BAZNAS)

Indonesia

khairunnajah@puskasbaznas.com

Noviyanti

Center of Strategic Studies

The National Board of Zakat (BAZNAS)

Indonesia

noviyanti@puskasbaznas.com 
